\title{
ДЕПОНИРОВАННЫЕ СТАТЬИ
}

Институтом геологии АН ЭССР в ВИНИТИ депонированы

следующие статьи

УдК $56.016: 551.733 .13(474,2)$

Я. НЫЛВАК

\section{РАСПРОСТРАНЕНИЕ КИСЛОТОУСТОЙЧИВЫХ МИКРО- ФОССИЛИИ В РАЗРЕЗАХ АШГИЛЛА СЕВЕРНОЙ ПРИБАЛТИКИ}

В статье рассмотрены общие черты литологического строения ашгиллских отложений в объеме верхнего подгоризонта набалаского и вормсиского, пиргуского и поркуниского горизонтов в разрезах западной части Северной Прибалтики, представленные разными литофациями начиная от отмельных известковых осадков с биогермными постройками до более глубоководных граптолитовых илов.

На основе таксономического изучения (не входит в рамки статьи) приведены детальные данные и выяснены основные закономерности распределения кислотоустойчивых микрофоссилий (хитинозой, акритарх, граптолоидей) в отложениях шести опорных разрезов. Среди хитинозой сравнительно четко выделяются виды с узким диапазоном вертикального распространения. Несмотря на их малочисленность (из 42 таксонов только 6), уровни их появления и исчезновения хорошо прослеживаются во всех изученных конфациальных зонах и часто независимы от литологического типа пород. Из остальных видов многие применимы для расчленения и сопоставления разрезов в пределах одной конфациальной зоны. Виды со спорадическим или широким вертикальным распространением при расчленении разрезов обычно не учитывались.

Вертикальное распространение установленных 17 видов акритарх по сравнению с хитинозоями более широкое и спорадическое.

Необходимо отметить, что при извлечении акритарх из изучаемых проб специальная методика препарирования не применялась. Они извлекались вместе с хитинозоями и их видовой состав явно обеднен: отсутствуют более мелкие формы. Однако уровни появления некоторых видов, распространенных и в низах силура, могут служить второстепенными критериями при расчленении разрезов.

Рабдосомы граптолоидей встречаются в ашгиллских отложениях очень редко. Гораздо чаще встречаемые сикулы биостратиграфического значения не имеют.

По хитинозоям в изученном стратиграфическом интервале выделено 14 биостратиграфических подразделений. Принятые реперы сопоставления подтверждают одновозрастность верхов кыргессаареской, тудулиннаской и фякаской свит вормсиского, а также моэской и тоотсиской свит пиргуского горизонтов. Предполагается возрастное несоответствие отложений оострикуской свиты в разрезах Средней Эстонии с «вермипорелловыми слоями» в разрезах о-ва Сааремаа, что может быть объяснено скольжением во времени фаций микро- и скрытокристаллических известняков с водорослями в верхней части пиргуского горизонта. Корреляционные критерии, выявленные в основном в 26 разрезах западной 
части Северной Прибалтики, требуют дальнейших уточнений в стратиграфически более полных разрезах Юго-Восточной Эстонии, поскольку в изученном районе отложения пиргуского и поркуниского горизонтов или выклиниваются, или не содержат изученных групп кислотоустойчивых микрофоссилий.

Рукопись депонировано 21/XII 1984 г. за № 8209-84. Текст 69 с. Рис. 22. Библ. 35 назв.

\author{
Д. КАЛЬО, Э.КЛААМАНН , В. ВИИРА, Р. МЯННИЛ, Т. МЯРСС, \\ B. НЕСТОР, Х. НЕСТОР, М. РУБЕЛЬ, Л. САРВ, Р. ЭИНАСТО
}

\title{
ЭКОСТРАТИГРАФИЧЕСКИЕ ОСНОВЫ БАССЕЙНОВОГО АНАЛИЗА (СИЛУР ПРИБАЛТИКИ)
}

В работе, подводящей итог 42 специальным исследованиям по экосистемному анализу силурийского бассейна Балтики, обоснованы следующие основные выводы:

1. Экосистемный анализ проводится с помощью ряда понятий (горизонт, свита, фация, фациальная зона, сообщество, палеоэкосистема), соотношения которых лучше всего раскрывают следующие схемы: 1) фациальная зональность бассейна; 2) местные стратиграфические подразделения; 3) изменение группового и трофического состава сообществ; 4) сопоставление биозональных стратиграфических схем по характерным группам организмов, характеризующих последовательно все фациальные зоны бассейна; 5) региональные стратиграфические подразделения. Их комплексное применение обеспечивает корреляцию всех разнофациальных свит бассейна (палеоэкосистем) и позволяет проследить, несмотря на литологический и фаунистический состав отложений, основные стратиграфические границы в пределах всего бассейна.

2. Седиментационный бассейн в целом, а также стратоны, объединяющие отложения бассейна, представлены двумя типами палеоэкосистем. Первый из них, базирующийся на внутреннем единстве и взаимосвязанном изменении среды и распространения биоты, служит основой местной стратиграфии (литостратиграфии). Второй, рассматривающий экосистему как бносферу, а ее развитие как последовательность палеоэкосистем (палеобиосфер), является основой хроностратиграфии.

Стратиграфические границы в этой схеме выступают как естественные границы изменения среды и биоты, происходящие или циклично (особенно ясно проявляется в мелководной части моря), или нециклично, проявляясь локально или (скользя во времени) почти по всему бассейну. Учитывая фациальный контроль распространения организмов выясняется, что разные стратиграфические границы, выступающие в роли границ палеоэкосистем, имеют различное распространение и характер (они изо- или диахронны).

Стратоны в качестве палеоэкосистем существенно изменяют роль палеонтологических данных. Если в «обыкновенной» стратиграфии остатки организмов выступают прежде всего в качестве «индикаторов времени», то в экостратиграфии биота является одной частью самого стратона. Это означает, что полноценные стратиграфические результаты 
немыслимы без системного анализа палеонтологического материала в комплексе со всеми остальными данными о фоссильной среде.

Исходя из приведенных рассуждений, в стратиграфической схеме бассейна имеются два типа стратиграфических границ: 1) границы местных стратонов, проведенные по изменению определенных параметров, обусловленные локальными биотическими или абиотическими факторами; 2) границы региональных (хроностратиграфических) стратонов, отражающие этапность развития бассейна. Моделью соотношений названных типов границ и стратонов мы считаем понятие «горизонт» из стратиграфической практики в СССР.

3. Биозона никогда не может быть планетарной, так как ее определение требует присутствия зонального вида или ассоциации. Это требование невыполнимо в разнофациальных отложениях. Биостратиграфическая зона (напр., стандартные граптолитовые зоны силура) в роли хронозоны выступает лишь тогда, когда в ее определение будут включены представители разнофациальной фауны.

Рукопись депонирована 4/VI 1985 г. за № 3738-85. Текст 42 с. Библ, 56 назв.

УдК $550.4: 549.905 .1(474)$

\section{Л. БИТЮКОВА}

\section{ФАЦИАЛЬНАЯ ИЗМЕНЧИВОСТЬ СОСТАВА СИДЕРИТОВ ВЕНДА И КЕМБРИЯ СЕВЕРНОЙ ПРИБАЛТИКИ}

В статье рассматриваются закономерности изменения содержаний 15 микроэлементов в основных морфологических типах сидеритов венда и кембрия Северной Прибалтики, а также прослеживается изменение содержаний данных элементов в зависимости от приуроченности сидеритов к фациальным зонам соответствующих палеобассейнов.

В венде сидеритообразование приурочено к отложениям котлинской свиты и является основным процессом образования новых минеральных форм в ходе диагенеза. Оно происходило в бассейне, характеризовавшимся быстрым темпом осадконакопления, что влекло за собой подавленность других процессов аутигенного минералообразования. В кембрии, в ирбенской свите, сидеритообразованию уже не принадлежит ведущая роль и сидеритовые образования сопряжены с рудопроявлениями бурых оолитовых железных руд.

Анализ характера распределения элементов в сидеритах различных морфологических форм котлинской свиты показал, что содержания подавляющего большинства изученных микроэлементов в них весьма близки. Наиболее выдержанными содержаниями характеризуются $\mathrm{Cr}$, $\mathrm{Ni}, \mathrm{V}, \mathrm{Zn}, \mathrm{Cu}, \mathrm{Sr}$ и В. Однако сидеритовые образования, приуроченные к наиболее дисперсным отложениям и имеющие обычно слоеобразную и линзовидную форму, отличаются от других морфологических типов сидеритов повышением содержаний $\mathrm{Pb}$ и $\mathrm{Ag}$, а конкреции изометрического облика - повышением содержаний Мо и Ag. Развивающиеся по наиболее грубодисперсным прослоям сидериты цементного типа отличаются самыми низкими содержаниями $\mathrm{Mn}, \mathrm{Pb}, \mathrm{Zn}$ и $\mathrm{Zr}$. Таким образом, судя по полученным данным, литологический тип вмещающей породы, определяющий морфологический облик формирующихся конкреционных 
образований, оказывает определенное влияние на содержание в них микроэлементов, обеспечивая исходный уровень последних в отложениях, подвергавшихся диагенетическим преобразованиям.

Сидериты венда и кембрия заметно различаются по абсолютным содержаниям в них микроэлементов. Так, для сидеритов ирбенской свиты установлены более высокие содержания $\mathrm{Co}, \mathrm{Ni}, \mathrm{V}$ и $\mathrm{Ba}$ по сравнению с сидеритовыми образованиями котлинской свиты, в то время как последние имеют более высокие содержания $\mathrm{Pb}, \mathrm{Ag}$ и $\mathrm{Sr}$. Вместе с тем, сидериты венда и кембрия характеризуются весьма близкими коэффициентами накопления $\mathrm{Cr}, \mathrm{Cu}, \mathrm{Mo}, \mathrm{Zn}$ и $\mathrm{Zr}$ относительно вмещающих пород соответствующих свит.

Для сидеритов, формировавшихся в различных фациальных зонах палеобассейнов, установлено, что те из них, образование которых происходило в относительно прибрежной и мелководной зонах, выделяются повышенным содержанием $\mathrm{Mn}, \mathrm{Zr}, \mathrm{Ni}, \mathrm{Zn}, \mathrm{Pb}, \mathrm{Cu}$ и $\mathrm{Ga}$. В сидеритах более глубоководных зон бассейна отмечается увеличение содержаний $\mathrm{Sr}$. Наибольшей контрастностью содержаний в сидеритах разнофациальных зон отличаются $\mathrm{Pb}, \mathrm{Mn}, \mathrm{Mo}, \mathrm{Cu}$ и $\mathrm{V}$.

Установлено, что сидеритообразование в отложениях котлинской свиты, развивающееся в условиях минимального количества сульфидного иона характеризуется накоплением в сидеритах халькофильных элементов, в частности $\mathrm{Pb}, \mathrm{Ag}$ и $\mathrm{Mo}$, а также $\mathrm{Sr}$. Это позволяет допустить вслед за М. Ф. Стащуком $(1968,1973)$, Ю. П. Мельником и др. (1973), что в ирбенских отложениях данные элементы мобилизировались уже на начальной стадии диагенеза и фиксировались в пиритовых образованиях, поскольку в случае парагенезиса пирит - сидерит, последний может быть лишь более поздним образованием в средах с развивающейся сульфатредукцией.

Рукопись депонирована 13/IX 1985 г. за № 6663-85. Текст 8 с. Табл. 4. Библ. 14 назв. 